\title{
ANALISIS TINGKAT PENGEMBALIAN DAN RISIKO INVESTASI (STUDI PADA INDUSTRI MANUFAKTUR YANG TERDAFTAR DI BURSA EFEK INDONESIA)
}

\author{
Afriyeni, Doni Marlius \\ Akademi Keuangan dan Perbankan Padang \\ afriyeni@akbpstie.ac.id
}

\begin{abstract}
The purpose of this study is to find out how much the rate of return earned on investments in banking companies studied, to find out how to obtain the level of risk in the stock investment banking firm selected as a sample, and to determine how the analysis of macroeconomic variables on the level risk and rate of return on investments in companies studied. In this study, the population is banking companies listed in Indonesia Stock Exchange (BEI) from 2005 to 2007 as many as 30 companies. The samples studied were limited to 10 banking companies from 2005-2007. The method used was purposive sampling method. Based on the calculations, the rate of return and the highest level of risk that is happening at PT. Kimia Farma (Persero) Tbk amounting to $8 \%$ with a risk level of $24.86 \%$ and the lowest or loss (capital loss) that is on the PT. Kalbe Farma Tbk was $-0.08 \%$ with a $6.77 \%$ risk level that occurred in 2007. From the years 2005-2007 the value of GDP has fallen so the rate of return of each stock is not worth the risk to be faced. In the last three months in 2005 until September 2006, inflation ranged between 14\% -19\% and in October 2006 through the end of 2007, the inflation rate did not exceed 7\%. With high inflation, the stock returns at year-end 2005 to end 2006 down and inflation is down and the rate of return of sahampun began to increase. At the end of 2005 not only the value of high inflation, but the SBI interest rate is also high and the weakening of the rupiah against the U.S. dollar resulted in the investment climate in Indonesia is not good enough for investors.
\end{abstract}

Keyword: investment, risk, rate of return, stocks, inflation, GDP, SBI, exchange rate.

\section{PENDAHULUAN}

Peristiwa krisis moneter di Indonesia yang terjadi sekitar pertengahan bulan Juli 1997 telah merusak berbagai sektor ekonomi maupun soaial. Krisis moneter yang berkepanjangan ini mulai menjalar menuju krisis ekonomi yang dipicu oleh depresiasi rupiah terhadap dollar yang berawal pada tanggal 17 Juli 1997. Nilai tukar ini bergejolak terus bahkan pernah menembus angka Rp 20.000,00 per US\$.

Salah satu kebijakan yang ditempuh pemerintah guna mengurangi gejolak nilai tukar tersebut yaitu dengan menaikkan suku bunga melalui instrumen Sertifikat Bank Indonesia (SBI) dan Surat Berharga Pasar Uang (SBPU), yang selanjutnya diikuti oleh kenaikan suku bunga bank-bank komersial pemerintah maupun swasta dengan harapan agar masyarakat tidak lagi membeli dollar, akan tetapi menyimpan dananya dalam bentuk deposito yang memberikan pendapatan (return) yang cukup tinggi yaitu mencapai $60 \%$ per tahun. 
Berfluktuasinya nilai rupiah dan kebijakan pemerintah menaikkan suku bunga SBI membawa dampak pada hampir semua aktifitas perekonomian, termasuk aktivitas Bursa Efek. Dampak yang ditimbulkan dapat dilihat dari anjloknya kinerja Bursa Efek di Indonesia, seperti penurunan Indeks Harga Saham Gabungan (IHSG) yang merupakan indeks dari dari semua saham yang terdaftar di bursa, nilai kapitalisasi pasar, nilai bersih asset (NAV) Reksadana, nilai transaksi obligasi maupun jumlah perusahaan atau emiten yang listing di Bursa Efek.

Sektor manufaktur di Indonesia yang umumnya, masih tergantung pada perkembangan di luar negeri dimana, sebagian besar dari bahan baku merupakan barang impor dan begitu juga hutangnya berasal dari luar negeri. Dengan adanya depresi rupiah terhadap dolar menyebabkan biaya produksi semakin tinggi sehingga berdampak tingginya harga produk. Tingginya harga produk secara keseluruhan menyebabkan terjadinya inflasi yang menyebabkan daya beli masyarakat menjadi rendah yang berefek pada rendahnya penjualan. Krisis ini, bertambah parah dengan naiknya tingkat suku bunga sehingga banyak perusahaan yang kesulitan untuk menambah modalnya.

Kondisi krisis pada sektor tersebut telah menyebabkan penurunan kinerja pada Bursa Efek Indonesia (BEI). Bagi investor, Emiten dan pihak bursa efek, sebagai penyelenggara pasar modal maupun pelaku pasar lainnya, hal ini tentu saja membawa konsekuensi tertentu. Bagi investor, melakukan investasi di Bursa Efek pada saat terjadinya krisis ekonomi merupakan investasi yang sangat berisiko menyebabkan turunnya harga saham-saham perusahaan yang telah terdaftar dalam Bursa Efek. Hal ini dapat dilihat bahwa dengan bergejolaknya nilai tukar rupiah terhadap US\$ dan tingkat suku bunga ternyata langsung ditanggapi oleh pelaku Bursa Efek di Indonesia. Banyak investor yang mengalihkan investasinya dari saham, obligasi dan reksadana ke pasar uang yang ternyata memang memberikan pengembalian (return) yang lebih tinggi dan mempunyai risiko yang lebih kecil dibanding kalau melakukan investasi dalam bentuk saham, obligasi maupun reksadana.

Menurut Tadelilin $(2001 ; 13)$ Risiko merupakan kemungkinan perbedaan antara return aktual yang diterima dengan return yang diharapkan. Suatu investasi akan selalu berkaitan dengan tingkat risiko, atau dengan kata lain, tingkat risiko merupakan suatu hal yang melekat pada setiap alternatif investasi. Oleh karena itu suatu perusahaan harus memiliki kombinasi keputusan-keputusan dalam melakukan investasi, keputusankeputusan ini mempengaruhi nilai perusahaan melalui pengaruhnya pada faktor tingkat keuntunganyang diharapkan dan tingkat risiko, karena tingkat keuntungan bagi para pemegang saham bersifat tidak pasti, sehingga perlu dipertimbangkan.

Dalam setiap pengambilan keputusan investasi, selain mempertimbangkan faktor pendapatan yang diharapkan (Expected Return), investor juga harus mempertimbangkan faktor risiko (risk) yang akan timbul dari alternatif investasi yang akan dilakukan, karena besar kecilnya risiko yang terkandung dalam suatu alternatif investasi akan mempengaruhi tingkat pendapatan yang diharapkan dari investasi tersebut. Penilaian investor atau calon investor terhadap risiko investasi saham juga akan mempengaruhi harga saham yang bersangkutan. Hal ini disebabkan karena risiko merupakan salah satu unsur dalam menentukan tingkat diskon untuk menentukan nilai suatu saham. Jika risiko investasi semakin tinggi, sementara pendapatan tetap, maka nilai saham akan semakin rendah sehingga dapat menyebabkan harga saham turun demikian pula sebaliknya.

Risiko investasi saham terdiri atas risiko sistematis dan risiko tidak sistematis. Risiko sistemasti adalah risiko yang timbul karena faktor-faktor yang bersifat makro 
dan mempengaruhi semua perusahaan atau industri serta tidak dapat dikurangi walaupun melalui diversifikasi. Faktor-faktor tersebut adalah pertumbuhan ekonomi, tingkat bunga deposito, nilai tukar valuta asing, tingkat inflasi dan kebijakan pemerintah di bidang ekonomi. Sedangkan risiko tidak sistematis adalah risiko yang melekat pada investasi tertentu karena kondisi yang unik dari suatu perusahaan atau industri. Risiko ini dapat dikurangi melalui diversifikasi. Risiko yang temasuk dalam kelompok ini dalah risiko kegagalan karena kondisi intern perusahaan, risiko kredit atau financial, risiko manajemen dan lain-lain.

Seorang investor wajar jika mengharapkan tingkat return yang tinggi dari investasi yang dilakukannya, tetapi ada hal penting yang harus dipertimbangkan, yaitu berapa besar risiko yang harus ditanggung dari investasi tersebut. Risiko bisa diartikan sebagai penyimpangan (return) yang diperoleh dari rencana hasil (return) yang diharapkan. Sikap investor terhadap risiko akan sangat tergantung pada preferensi investor tersebut terhadap risiko. Investor yang lebih berani akan memilih risiko investasi yang lebih tinggi, yang diikuti oleh harapan tingkat return yang tinggi juga. Demikian sebaliknya, investor yang tidak mau menanggung risiko yang tinggi, tentunya tidak akan bisa mengharapkan tingkat return yang tinggi pula.

Seorang investor membeli sejumlah saham pada saat ini dengan harapan akan memperoleh keuntungan dari kenaikan harga saham ataupun sejumlah deviden di masa yang akan datang. Pada dasarnya tujuan investor melakukan investasi adalah untuk menghasilkan sejumlah uang. Sedangkan tujuannya secara luas adalah untuk meningkatkan kesejahteraan investor.

Menurut Tandelilin (2001;5) menyatakan bahwa hubungan tingkat risiko dan tingkat return yang diharapkan dari suatu investasi merupakan hubungan yang searah atau linier. Artinya semakin besar tingkat risiko yang harus ditanggung oleh investor terhadap saham yang dimilikinya, maka semakin besar pula tingkat return yang diharapkan. Sebaliknya, semakin kecil tingkat risiko yang harus ditanggung oleh investor terhadap saham yang dimilikinya, maka semakin kecil pula tingkat return yang diharapkan

Berdasarkan uraian diatas dan penelitian yang berkaitan dengan risiko investasi pada saham, penulis juga mencoba menganalisa risiko dan tingkat pengembalian investasi saham di pasar modal khususnya Industri manufaktur di Bursa Efek Indonesia. Sektor manufaktur dipilih karena berdasarkan data Biro Pusat Statistik (BPS), sektor ini memberikan kontribusi terbesar pada Produk Domestik Bruto (PDB) Indonesia. Misalnya saja pada tahun 2005, sektor manufaktur mampu memberikan kontribusi sebesar 20,84\% terhadap PDB. Industri manufaktur dan industri pengolahan di Indonesia pada umumnya masih tergantung pada perkembangan di luar negeri, dimana sebagian besar dari bahan bakunya merupakan barang impor, disamping itu sebagian besar alat produksinya (mesin-mesinnya) adalah produk dari luar negeri yang biasanya dibeli dalam bentuk hutang jangka panjang. Akibat terjadinya depresiasi rupiah terhadap dollar menyebabkan biaya produksi semakin tinggi, kemudian berdampak pada tingginya harga produk dan nilai hutang dalam rupiah akan semakin membesar. Tingginya harga produk secara keseluruhan menyebabkan terjadinya inflasi yang menyebabkan daya beli masyarakat menjadi rendah, sehingga mengakibatkan rendahnya penjualan. Keadaan ini bertambah parah dengan naiknya tingkat suku bunga sehingga banyak perusahaan yang kesulitan dalam menambah modalnya. 


\section{TINJAUAN LITERATUR \\ Pasar Modal}

Pasar modal (capital market) merupakan pasar untuk berbagai intrumen keuangan (atau sekuritas) jangka panjang yang bisa diperjualbelikan, baik dalam bentuk hutang atapun modal sendiri, baik yang diterbitkan oleh pemerintah, public authorities, maupun perusahaan swasta. Dengan demikian pasar modal merupakan konsep yang lebih sempit dari pasar keuangan (Husnan, 2001).

Menurut Tandelilin $(2001 ; 13)$ Pasar modal ialah pertemuan antara pihak yang memiliki kelebihan dana dengan pihak yang membutuhkan dana dengan cara memperjualbelikan sekuritas. Dengan demikian, pasar modal juga bisa diartikan sebagai pasar untuk memperjualbelikan sekuritas yang umumnya memiliki umur lebih dari satu tahun, seperti saham dan obligasi. Sedangkan tempat dimana terjadinya jual beli sekuritas disebut dengan bursa efek. Oleh karena itu, bursa efek merupakan arti dari pasar modal secara fisik.

Berdasarkan Undang-Undang No. 8 Tahun 1995 tentang Pasar Modal, Pasar Modal adalah kegiatan yang bersangkutan dengan penawaran umum dan perdagangan efek, perusahaan public yang berkaitan dengan efek yang diterbitkannya, serta lembaga dan profesi yang berkaitan dengan efek. Sedangkan pengertian umum pasar modal (capital market) adalah institusi/tempat dan prosedur atau sistem yang memberikan sarana untuk penciptaan dan transfer/transaksi instrument keuangan jangka panjang.

\section{Pelaku Pasar Modal}

Berdasarkan Keppres No. 53 tahun 1990 yang dijabarkan dalam keputusan Menteri Keuangan No. 1548/KMK.013/1990 seperti dikutip dalam "promosi dan informasi pasar modal Indonesia, para pelaku pasar modal dibagi atas sembilan bagian, yaitu : Badan Pengawas Pasar Modal (Bapepam), Bursa Efek, Lembaga Kliring Penyelesaian dan Penyimpanan, Reksa Dana, Perusahaan Publik (Emiten), Perusahaan Efek, Penjamin Emisi Efek, Perantara Pedagang Efek, Manajer Investasi, Penasehat investasi, dan Investor

\section{Instrumen Pasar Modal}

Menurut Tandelilin $(2001 ; 18)$ beberapa sekuritas yang umumnya diperdagangkan di pasar modal antara lain :

\section{a. Saham}

Saham merupakan surat bukti bahwa kepemilikan atas aset-aset perusahaan yang menerbitkan saham dengan memiliki saham suatu perusahaan.

b. Obligasi

Obligasi merupakan surat bukti bahwa investor pemegang obligasi memberikan pinjaman utang bagi emiten penerbit obligasi.

c. Reksadana

Reksadana (mutual fund) adalah sertifikat yang menjelaskan bahwa pemiliknya menitipkan sejumlah dana kepada perusahaan reksadana untuk digunakan sebagai modal berinvestasi baik dipasar modal maupun pasar uang

d. Instrumen Derivatif (opsi dan futures)

Instrumen derivatif merupakan sekuritas yang nilainya merupakan turunan dari suatu sekuritas lain, sehingga nilai instrumen derivatif sangat tergantung dari harga sekuritas lain yang ditetapkan sebagai patokan.

\section{Risiko Investasi Saham}

Menurut Husnan (1994;145) risiko dapat diartikan sebagai kemungkinan keuntungan yang sebenarnya yang menyimpang dari keuntungan yang 
diharapkan.Sedangkan menurut Tandelilin ( 2001;13) risiko merupakan kemungkinan perbedaan antara return aktual yang diterima dengan return yang diharapkan. Risiko investasi saham dikelompokkan menjadi risiko sistematis dan risiko tidak sistematis. Risiko tersebut dipengaruhi oleh faktor-faktor yang bersifat makro dan faktor-faktor yang bersifat mikro, yaitu meliputi:

Faktor-faktor yang bersifat makro yaitu:

1. Kondisi Ekonomi

Merupakan keadaan dimana perekonomian mengalami resesi, berkembang atau dalam keadaan stabil. Dalam keadaan resesi, biasanya banyak perusahaan yang mengalami kesulitan dalam memasarkan hasil produksinya. Hal ini disebabkan karena daya beli masyarakat menurun, akibatnya para investor enggan untuk membeli saham sehingga harga saham akan turun, maka risiko akan besar.

2. Tingkat bunga

Apabila tingkat bunga deposito meningkat, maka investor akan lebih memilih deposito sebagai tempat untuk menginvestasikan dananya. Sebaliknya jika tingkat bunga deposito menurun, maka investor akan memilih untuk menginvestasikan dananya ke pasar modal.

3. Tingkat Inflasi

Merupakan indikator terjadinya kenaikkan harga barang-barang. Dalam tingkat inflasi yang cukup tinggi, investor tidak mampu untuk membeli saham yang diperdagangkan di bursa, akibatnya harga saham akan turun dan risiko investasi atas saham akan semakin besar.

4. Kurs valuta asing

Adalah perbandingan antara nilai mata uang suatu negara dengan nilai mata uang negara lain. Fluktuasi kurs yang tinggi dapat merangsang investor untuk membeli valuta asing tersebut. Pada saat adanya isu tentang depresiasi, investor akan mengalihkan investasinya dalam bentuk valuta asing. Akibatnya harga saham akan turun dan risiko investasi atas saham akan semakin besar.

Faktor-faktor yang bersifat mikro yaitu:

1. Kebijakan pemerintah dibidang ekonomi.

Meliputi berbagai perangkat peraturan dalam bentuk regulasi dan deregulasi yang bertujuan untuk meningkatkan pertunbuhan perekonomian dan pasar modal,terutama di bidang fiskal dan moneter. Jika pemerintah menetapkan suatu regulasi yang menguntungkan pasar modal, misalnya melindungi para investor yang berinvestasi dalam kondisi perekonomian yang resesi, maka risiko investasi akan dapat dikurangi.

2. Struktur modal

Struktur modal suatu perusahaan ditunjukkan dengan perbandingan antara penggunaan hutang jangka panjang dan modal sendiri. Struktur modal ini mencerminkan kebijakan pembelanjaan jangka panjang perusahaan. Jika penggunaan hutang jangka panjang lebih besar dari penggunaan modal sendiri, maka perusahaan akan menanggung risiko pembayaran hutang yang cukup besar. Akibatnya kan mengurangi perolehan laba perusahaan dan akan memperbesar risiko investasi saham yang akan dilakukan oleh investor.

3. Struktur Aktiva

Mencerminkan kebijakan investasi perusahaan dalam berbagai aktiva. Operating leverage timbul karena dalam melakukan operasinya perusahaan menggunakan aktiva dengan biaya tetap berupa biaya penyusutan. Jika struktur aktiva 
perusahaan terdiri dari saham-saham, maka perusahaan akan menanggung kewajiban untuk membayar deviden kepada investor. Dan jika perusahaan tidak sanggup untuk membayar deviden karena rugi, maka risiko investasi atas saham akan semakin besar, sehingga investor akan menanggung kerugian.

4. Laba perlembar saham (EPS = Earning Per Share)

Jika investor berinvestasi pada saham perusahaan dengan EPS yang besar, maka deviden yang diharapkan investor akan semakin besar, akibatnya risiko investasi atas saham akan semakin kecil.

\section{Keuntungan dan risiko investasi saham}

Pasar modal memberikan banyak alternatif investasi pada berbagai jenis efek yang diinginkan dibandingkan dengan sektor perbankan. Beberapa keuntungan yang diperoleh dari memiliki saham (Jakarta Stock Exchange:1996) adalah :

1. Kemungkinan memperoleh capital gain, yaitu selisih positif antara harga pada saat membeli saham dibandingkan pada saat menjual saham tersebut efek.

2. Memiliki hak prioritas untuk membeli bukti right yang dikeluarkan perusahaan

3. Kemungkinan memperoleh deviden berupa uang tunai atau saham (saham deviden) kalau perusahaan berkembang baik

4. Kemungkinan memperoleh hak saham atas bonus

5. Waktu kepemilikan tidak terbatas dan berakhir pada saat investor menjual kembali saham tersebut di bursa efek.

6. Memiliki hak suara di RUPS.

\section{Return}

Tujuan investor dalam berinvestasi adalah memaksimalkan return, tanpa harus melupakan faktor risiko investasi yang harus dihadapinya. Return merupakan salah satu faktor yang memotivasi investor berinvestasi dan juga merupakan imbalan atas keberanian investor dalam menanggung risiko atas investasi yang dilakukanya.

Sumber return investasi terdiri dari dua komponen utama, yaitu yield dan capital gain (loss). Yield merupakan return yang mencerminkan aliran kas atau pendapatan yang diperoleh secar periodik dari suatu investasi. Sedangkan capital gain (loss) merupakan kenaikkan atau penurunan harga suatu surat berharga (bisa saham maupun surat hutang jangka panjang), yang memberikan keuntungan atau kerugian bagi investor (Tandelilin, 2001).

\section{Investasi}

Secara sederhana investasi diartikan sebagai suatu kegiatan menempatkan dana pada satu atau lebih dari asset selama periode tertentu dengan harapan dapat memperoleh penghasilan atau peningkatan nilai investasi. Memegang uang kas atau uang tunai bukan merupakan investasi karena tidak memberikan penghasilan dan nilainya akan turun jika terjadi inflasi. Sebaliknya, merupakan dana pada tabungan atau membeli saham merupakan investasi, karena selain memberikan return, nilainya juga dapat diharapkan meningkat dimasa yang akan datang.

Tujuan dari investasi adalah untuk meningkatkan kesejahteraan para investor dan untuk mendapatkan keuntungan baik di masa sekarang maupun dimasa yang akan datang dari aktivitas yang dilakukan pada saat ini. Keuntungan akan diperoleh melalui aktivitas investasi yang dilakukan dengan mengorbankan sejumlah dana pada saat ini dengan harapan pengembalian sejumlah tertentu dimasa yang akan datang (Tandelilin,2001).

Dengan demikian, aktivitas investasi dalam bentuk apapun memerlukan analisis secara mendalam, terutama menyangkut analisis keuangannya. Alasannya adalah karena 
aktifitas investasi akan membawa dampak kepada masalah keuangan dan akhirnya akan berpengaruh terhadap tujuan perusahaan. Melalui analisis yang cukup, diharapkan aktivitas investasi dapat mencapai tujuan perusahaan secara umum, yaitu memaksimumkan kesejahteraan para pemegang saham.

\section{Prinsip Dasar Investasi : Risk Return Trade Off}

Dalam melakukan investasi seorang investor akan memperkirakan berapa tingkat penghasilan yang diharapkan (expected return) atas investasinya untuk suatu periode tertentu di masa yang akan datang. Namun setelah periode investasi berlalu, belum tentu tingkat penghasilan yang terealisasi adalah sama dengan tingkat penghasilan yang diharapkan. Tingkat penghasilan yang terealisasi dapat lebih tinggi atau lebih rendah.

Ketidakpastian akan tingkat penghasilan merupakan inti dari investasi yaitu bahwa investor harus selalu mempertimbangkan unsur ketidakpastian yang merupakan resiko investasi. Investasi pada Sertifikat Bank Indonesia (SBI) dapat dikatakan tidak berisiko, karena dapat dipastikan bahwa Bank Indonesia akan melunasi kewajibannya pada saat jatuh tempo. Karena risikonya sangat rendah, maka asset tersebut hanya dapat menjanjikan penghasilan yang relatif rendah. Investasi pada saham mempunyai risiko yang tinggi, karena besar sekali kemungkinan bahwa penghasilan yang diharapkan pada suatu periode tertentu tidak dapat direalisasikan. Akan tetapi karena tingkat risikonya yang lebih tinggi, maka asset tersebut menjanjikan penghasilan yang jauh lebih besar. Dengan demikian dapat disimpulkan bahwa "Trade Off" atau tukar impas antara penghasilan dan tingkat risiko.

\section{Saham}

Umumnya instrumen surat-surat berharga yang diperdagangkan dipasar modal dapat dibedakan atas surat berharga yang bersifat kepemilikan dan surat berharga yang bersifat hutang. Surat berharga yang bersifat kepemilikan disebut dengan saham. Saham diterbitkan dan dijual oleh perusahaan-perusahaan yang sudah terdaftar di bursa efek (go public) dengan tujuan untuk mengumpulkan dana sebanyak-banyaknya untuk keperluan pembiayaan perusahaan.

Menurut Tandelilin (2001) saham merupakan surat bukti kepemilikan atas asset perusahaan yang menerbitkan sekuritas tersebut. Definisi saham menurut Peraturan BAPPEPAM ( $1989 ; 12$ ) saham yang dimaksud kepada kepemilikan itu sendiri dalam bentuk surat saham yang sering disebut saham saja, hanya merupakan bukti kepemilikan itu sendiri. Dengan demikian saham berfungsi untuk mentransportasi kekayaan nyata dalam bentuk surat berharga yang dapat diperdagangkan atau kepemilikannya dapat dipindahtangankan dari suatu pihak ke pihak yang lain.

Memiliki saham suatu perusahaan, maka manfaat yang dapat diperoleh antara lain:

1. Deviden, adalah bagian dari keuntungan perusahaan yang dibagikan kepada para pemegang saham.

2. Capital gain, adalah keuntungan yang diperoleh dari selisih kenaikkan harga pada waktu menjual dengan harga pada waktu membeli.

3. Manfaat non ekonomis, yaitu timbulnya kebanggaan dan kekuasaan memperoleh hak suara menentukan jalannya perusahaan.

Dalam kepemilikannya, seorang investor akan menghadapi kemungkinan untung dan kemungkinan rugi. Investor akan memperoleh keuntungan apabila saham perusahaan tersebut mengalami pertumbuhan yang baik dan akan memberikan deviden yang memuaskan. Jika tidak ada pembagian deviden, perusahaan akan tetap memiliki keuntungan lain dari nilai riil saham yang akan meningkatkan dengan adanya 
perkembangan struktur modal, selain itu keuntungan mungkin saja di dapat dari penjual saham (capital gain).

Sebaliknya, seorang investor akan mengalami kerugian apabila saham dikeluarkan oleh perusahaan tidak mengalami pertumbuhan dengan baik. Jika para pemegang saham menjual saham dipasar sekunder, kemungkinan yang mereka peroleh adalah kerugian secara nominal maupun secara riil (jika keuntungan nilai waktu dari uang) atau capital loss.

Dengan demikian, dapat disimpulkan bahwa disatu sisi saham merupakan efek yang mengandung risiko, namun disisi lain saham merupakan alat investasi yang akan menjamin keuntungan berupa deviden dan capital gain.

\section{Penelitian Terdahulu}

Berdasarkan penelitian terdahulu yang dilakukan oleh Mulyatri (1994), tentang risiko portofolio saham pada perusahaan sektor perbankan yang go public di Indonesia. Dimana hubungan risiko terhadap return adalah signifikan karena perubahan proporsi dana menyebabkan berubahnya risiko portofolio. Jahja (1997), tentang Risk dan Return terhadap perusahaan BUMN sektor Perbankan yang go public di Indonesia. Dari analisa regresi yang dilakukan ternyata terdapat pengaruh yang signifikan antara return yang diterima terhadap risiko yang dihadapi. Penelitian tentang risk juga pernah diteliti oleh Triwilnawati (2000) yaitu tentang Analisis Pengukuran Risk and Return Investasi saham pada perusahaan yang go public. Dimana mengambil 5 sampel perusahaan berdasarkan saham yang memiliki return tertinggi selama 30 bulan. Semakin tinggi investasi saham yang ditanamkan, maka semakin tinggi pula return yang akan diterima. Ini berarti return mempunyai hubungan yang signifikan dengan risiko yang dihadapi.

\section{Metode Penelitian}

\section{Populasi dan Sampel}

Populasi penelitian ini adalah semua perusahaan manufaktur yang terdaftar di Bursa Efek Indonesia (BEI). Berdasarkan kriteria pemilihan sampel, maka terdapat 15 perusahaan manufaktur yang go public dari tahun 2005 sampai dengan tahun 2007. Metode yang digunakan dalam penelitian ini adalah metode purposive sampling. Dimana pengambilan sampel ditentukan dengan kriteria sesuai dengan kebutuhan penelitian ini. Kriteria pengambilan sampel yang ditetapkan adalah sebagai berikut : 
Tabel 1.

Jumlah Perusahaan dan Jenis Industri yang menjadi Sampel Penelitian

\begin{tabular}{|c|l|l|}
\hline No & \multicolumn{1}{|c|}{ Perusahaan } & \multicolumn{1}{c|}{ Jenis Industri } \\
\hline 1 & PT. Aqua Golden Mississippi Tbk & Food and Beverages \\
\hline 2 & PT. Indofood Sukses Makmur Tbk & Food and Beverages \\
\hline 3 & PT. Gudang Garam Tbk & Tabacco Manufacture \\
\hline 4 & PT. HM Sampoerna Tbk & Tabacco Manufacture \\
\hline 5 & PT. Berlina Tbk & Plastic and Glass Produts \\
\hline 6 & PT. Semen Gresik (persero) Tbk & Cement \\
\hline 7 & PT. Gajah Tunggal Tbk & Automotive \\
\hline 8 & PT. Goodyear Indonesia Tbk & Automotive \\
\hline 9 & PT. Selamat sempurna Tbk & Automotive \\
\hline 10 & PT. Kalbe Farma & Pharmaceuticals \\
\hline 11 & PT. Kimia Farma (persero) Tbk & Pharmaceuticals \\
\hline 12 & PT. Siantar Top Tbk & Consumer Goods \\
\hline 13 & PT. Mustika Ratu Tbk & Consumer Goods \\
\hline 14 & PT. Unilever Indonesia Tbk & Consumer Goods \\
\hline 15 & PT. Dynaplast Tbk & Plastic and Glass Produts \\
\hline
\end{tabular}

Sumber : Indonesian Capital Market Directory

\section{Definisi Operasional}

a. Tingkat resiko yang merupakan kemungkinan keuntungan yang diperoleh menyimpang dari keuntungan yang diharapkan yang diukur dengan deviasi standar.

b. Tingkat pengembalian merupakan imbalan atas keberanian investor dalam menanggung resiko atas investasi yang dilakukannya yang diatur dengan expected return.

c. Investasi saham merupakan suatu investasi yang dilakukan oleh investor dalam bentuk saham.

\section{Pengukuran Variabel}

Penilaian usulan investasi didasarkan atas dua parameter yaitu nilai atau keuntungan yang diharapkan dan deviasi standar (risk).

1. Tingkat keuntungan dapat diperoleh dengan rumus:

$$
R i=\frac{P i-p o}{p o}
$$

Dimana: $\quad \mathrm{Ri}=$ Tingkat keuntungan ke-I

Po = Harga saham pada periode sebelumnya

$\mathrm{Pi}=$ Harga saham pada periode sekarang.

2. Tingkat keuntungan yang diharapkan dari masing-masing saham:

$$
\mathrm{E}(\mathrm{R})=\sum_{t=1}^{n} \frac{R i}{n}
$$

Dimana : $\quad \mathrm{Ri}=$ Tingkat Keuntungan

$\mathrm{N}=$ Jumlah data

Resiko sering dihubungkan dengan penyimpangan atau deviasi dari outcome yang diterima dengan yang diharapkan. Oleh karenanya, dimensi risiko ada dua, yaitu menyimpang lebih kecil atau menyimpang lebih besar. Resiko diukur 
dengan menggunakan standar deviasi dari return yang diterima oleh investor, dimana standar deviasi dinyatakan sebagai berikut (Husnan,2001)

3. Deviasi standar masing-masing saham:

$$
\sigma=\sqrt{\sum_{t=1}^{n} \frac{\left(R i-\overline{R)^{2}}\right.}{n-1}}
$$

Dimana :

$$
\begin{aligned}
\sigma & =\text { Risiko investasi saham } \\
\mathrm{Ri} & =\text { Return saham pada periode } \mathrm{i} \\
\bar{R} \quad & =\text { Rata-rata return } \\
\mathrm{n} & =\text { Jumlah observasi }
\end{aligned}
$$

4. Tingkat bunga adalah tingkat bunga Sertifikat Bank Indonesia (SBI).

5. Kurs Valuta Asing adalah nilai tukar rupiah terhadap dollar amerika. Nilai tukar diukur dengan kurs rata-rata.

6. Tingkat Inflasi adalah tingkat inflasi yang diukur dengan pertumbuhan indeks harga konsumen.

7. Pertumbuhan ekonomi nasional diukur dengan pertumbuhan Produk Domestik Bruto (PDB).

\section{PEMBAHASAN}

Berdasarkan perhitungan tingkat pengembalian dan tingkat risiko selama 3 tahun (tahun 2005 - 2007) di atas dapat disimpulkan bahwa Kimia Farma (persero) Tbk memiliki tingkat pengembalian yang tinggi yaitu sebesar $8 \%$ dengan tingkat risiko sebesar 24,86\% pada tahun 2007 dan Kalbe Farme Tbk memiliki tingkat pengembalian yang terendah (loss) yaitu sebesar - $0.08 \%$ dengan tingkat risiko sebesar $6,77 \%$ pada tahun 2007. 
Tabel 2.

Tingkat Pengembalian dan Tingkat Risiko Tahun 2005 - 2007

\begin{tabular}{|c|c|c|c|c|c|c|}
\hline \multirow{2}{*}{$\begin{array}{c}\text { Nama } \\
\text { Perusahaan }\end{array}$} & \multicolumn{2}{|c|}{ Tahun 2005} & \multicolumn{2}{|c|}{ Tahun 2006} & \multicolumn{2}{|c|}{ Tahun 2007} \\
\hline & $\begin{array}{l}\text { Expected } \\
\text { Return \% }\end{array}$ & $\begin{array}{c}\text { Risk } \\
\%\end{array}$ & $\begin{array}{l}\text { Expected } \\
\text { Return \% }\end{array}$ & $\begin{array}{c}\text { Risk } \\
\%\end{array}$ & $\begin{array}{l}\text { Expected } \\
\text { Return \% }\end{array}$ & $\begin{array}{c}\text { Risk } \\
\% \\
\end{array}$ \\
\hline PT. Aqua Golden Mississippi Tbk & 2.93 & 7.32 & -8.43 & 31.56 & 0.95 & 7.6 \\
\hline PT. Indofood Sukses Makmur Tbk & 1.44 & 14.81 & 4.63 & 12.36 & 4.22 & 8.58 \\
\hline PT. Gudang Garam Tbk & -3.02 & 7.72 & 0.41 & 4.77 & -1.56 & 6.63 \\
\hline PT. HM Sampoerna Tbk & 2.09 & 10.4 & 1.41 & 5.92 & 1.9 & 7.41 \\
\hline PT. Berlina Tbk & -2.72 & 13.58 & -2.53 & 10.07 & 0.68 & 6.65 \\
\hline PT. Semen Gresik Tbk & 0.24 & 10.89 & 6.27 & 9.75 & -3.84 & 29.96 \\
\hline PT. Gajah Tunggal Tbk & -1.22 & 13.63 & -0.33 & 9.24 & -1.18 & 6.32 \\
\hline PT. Goodyear Indonesia Tbk & -0.92 & 5.68 & -1.78 & 9.07 & 7.93 & 12.5 \\
\hline PT. Selamat Sempurna Tbk & 0.29 & 5.56 & 0.6 & 3.76 & 3.45 & 10.23 \\
\hline PT. Kalbe Farma Tbk & 3.57 & 7.24 & -0.38 & 9.67 & -0.08 & 6.77 \\
\hline PT. Kimia Farma Tbk & 2.34 & 10.67 & 1.02 & 5.79 & 8 & 24.86 \\
\hline PT. siantar Top Tbk & -1.36 & 5.35 & 3.75 & 12.4 & 2.39 & 8.37 \\
\hline PT. Mustika Ratu Tbk & -3.42 & 7.92 & 2.14 & 9.84 & 0.75 & 9.61 \\
\hline PT. Unilever Tbk & 2.15 & 8.61 & 4.31 & 8.93 & 1.5 & 6.61 \\
\hline PT. Dynaplast Tbk & -3.22 & 6.53 & -3.02 & 6.89 & 1.57 & 11.06 \\
\hline Jumlah & -0.83 & 135.91 & 8.07 & 150.02 & 26.68 & 163.16 \\
\hline Rata-rata Industri & -0.06 & 9.06 & 0.54 & 10.00 & 1.78 & 10.88 \\
\hline
\end{tabular}

Sumber : Data Diolah

\section{Analisis Variabel Makro Terhadap Tingkat Risiko Dan Tingkat Pengembalian Investasi Saham}

Dalam penelitian ini hanya menggunakan 4 variabel makro ekonomi (PDB, inflasi, tingkat suku bunga SBI, dan kurs valuta asing). Dari tahun 2005 sampai dengan tahun 2007 nilai PDB menurun sehingga tingkat pengembalian dari masing-masing saham tidak sebanding dengan tingkat risiko yang akan dihadapi.

Pada tiga bulan terakhir di tahun 2005 sampai pada September 2006, inflasi berkisar antara 14\% - 19\% dan pada oktober 2006 hingga akhir 2007, inflasi tidak melebihi angka 7\%. Dengan tingginya inflasi maka tingkat pengembalian saham di akhir tahun 2005 menjadi turun dan di akhir tahun 2006 inflasi turun dan tingkat pengembalian dari saham pun mulai meningkat. Pada akhir tahun 2005 tidak hanya nilai inflasi yang tinggi, akan tetapi tingkat suku bunga SBI juga tinggi dan melemahnya nilai rupiah terhadap dollar Amerika mengakibatkan iklim investasi di Indonesia tidak cukup baik bagi investor.

Perubahan variabel makro ekonomi selama tiga tahun tersebut dapat dilihat pada tabel dibawah ini : 
Tabel 3.

Perubahan Variabel Makro Ekonomi Selama Tahun 2005 - 2007

\begin{tabular}{|l|c|c|c|}
\hline \multicolumn{1}{|c|}{ Variabel Makro Ekonomi } & Tahun 2005 & Tahun 2006 & Tahun 2007 \\
\hline PDB (\%) & 20.84 & 20.36 & 18.27 \\
\hline Inflasi (\%) & 10.40 & 13.33 & 6.40 \\
\hline Tingkat Suku Bunga SBI (\%) & 9.10 & 12.08 & 8.66 \\
\hline Nilai Tukar (Rp) & 9753.96 & 9325.71 & 9163.66 \\
\hline
\end{tabular}

Sumber : Data Diolah

Pertumbuhan PDB yang cepat merupakan indikasi terjadinya pertumbuhan ekonomi. Jika pertumbuhan ekonomi membaik, maka daya beli masyarakat pun akan meningkat, dan ini merupakan kesempatan bagi perusahaan-perusahaan untuk meningkatkan penjualannya. Dengan meningkatnya penjualan perusahaan, maka kesempatan perusahaan memperoleh keuntungan juga akan semakin meningkat. Meningkatnya PDB merupakan sinyal yang baik (positif) untuk beinvestasi dan sebaliknya jika PDB menurun. Meningkatnya PDB menyebabkan kondisi perbankan menjadi lesu sehingga investor lebih tertarik berinvestasi di pasar modal.

Peningkatan inflasi dapat mengurangi daya beli rupiah. Jika peningkatan biaya produksi lebih tinggi dari peningkatan harga yang dapat dinikmati oleh perusahaan maka profitabilitas perusahaan akan turun. Jika inflasi tinggi, kondisi perbankan akan menjadi lesu karena terjadinya kenaikan harga produk yang menyebabkan sedikitnya orang yang mau menabung. Secara umum, inflasi dapat menyebabkan berkurangnya investasi di suatu negara, mendorong tingkat bunga, mendorong penanaman modal yang bersifat spekulatif, kegagalan pelaksanan pembangunan, ketidakstabilan ekonomi, defisit neraca pembayaran, dan merosotnya tingkat kehidupan dan kesejahteraan masyarakat.

Tingkat bunga yang tinggi merupakan sinyal negatif terhadap harga saham. Tingkat suku bunga yang meningkat akan menyebabkan peningkatan suku bunga yang diisyaratkan atas investasi pada suatu saham. Di samping itu tingkat suku bunga yang meningkat bisa juga menyebabkan investor menarik investasinya pada saham dan memindahkannya pada investasi berupa tabungan ataupun deposito. Dengan demikian, jika suku bunga naik banyak orang yang menabung dan aktifitas di bank menjadi ramai.

Menguatnya kurs rupiah terhadap mata uang asing akan menurunkan biaya impor bahan baku untuk produksi. Menguatnya kurs rupiah terhadap mata uang asing merupakan sinyal positif bagi perekonomian yang mengalami inflasi. Jika kurs rupiah turun, orang akan banyak berinvestasi ke mata uang asing. Bila dilihat pada sektor perusahanan manufaktur, nilai mata uang asing ini sangat menentukan besar kecilnya risiko bisnis/perusahaan, karena sebagian besar dari komponen produksi adalah berasal dari barang impor.

\section{PENUTUP}

\section{Kesimpulan}

1. Dari perhitungan tingkat pengembalian dan tingkat risiko selama 3 tahun (tahun 2005-2007) dapat disimpulkan bahwa Kimia Farma (persero) Tbk memiliki tingkat pengembalian yang tinggi yaitu sebesar $8 \%$ dengan tingkat risiko sebesar $24.86 \%$ dan Kalbe Farma Tbk memiliki tingkat pengembalian yang terendah (loss) yaitu sebesar $-0.08 \%$ dengan tingkat risiko sebesar $6,77 \%$ pada tahun 2007 . 
2. Dari tahun 2005 sampai dengan tahun 2007 nilai PDB menurun sehingga tingkat pengembalian dari masing-masing saham tidak sebanding dengan tingkat risiko yang akan dihadapi. Pada tiga bulan terakhir di tahun 2005 sampai pada september 2006, inflasi berkisar antara 14\% - 19\% dan pada oktober 2006 hingga akhir 2007, inflasi tidak melebihi angka 7\%. Dengan tingginya inflasi maka tingkat pengembalian saham di akhir tahun 2005 menjadi turun dan di akhir tahun 2006 inflasi turun dan tingkat pengembalian dari saham pun mulai meningkat. Pada akhir tahun 2005 tidak hanya nilai inflasi yang tinggi, akan tetapi tingkat suku bunga SBI juga tinggi dan melemahnya nilai rupiah terhadap dollar Amerika mengakibatkan iklim investasi di Indonesia tidak cukup baik bagi investor.

\section{Saran}

1. Dalam rangka mengembangkan dan memasyarakatkan pasar modal di Indonesia, Bursa Efek Indonesia (BEI) sebagai lembaga pasar modal perlu memberikan informasi yang lebih lengkap, cepat dan murah kepada masyarakat luas tentang manfaat dan cara melakukan investasi pada saham di pasar modal. Hal ini dapat dilakukan dengan : a) Meningkatkan pengetahuan masyarakat tentang pasar modal yang dapat dilakukan melalui pendidikan formal maupun informal, b) Pengadaan informasi yang akurat tentang hal-hal yang berkaitan dengan pasar modal.

2. Pemerintah diharapkan dapat mempertahankan stabilitas ekonomi dengan tingkat pertumbuhan yang tinggi pada tahun berikutnya, terutama dibidang moneter (masalah nilai tukar) jangka panjang sehingga iklim investasi kondusif terwujud.

\section{DAFTAR PUSTAKA}

Afriyeni, 2003, Analisis Faktor-faktor Yang Mempengaruhi Risiko Investasi Pada Saham Perusahaan Manufaktur Di Bursa Efek Jakarta. Tesis Program Manajemen Keuangan Perbankan Syariah Pascasarjana STIE “ KBP” Padang, Tidak dipublikasikan

Afriyeni, A., \& Marlius, D. (2019). Analisis Faktor-Faktor Yang Berpengaruh Terhadap Ketepatan Waktu Penyampaian Laporan Keuangan Pada Perusahaan Yang Listing Di Bursa Efek Indonesia. https://doi.org/10.31219/osf.io/rv4qf

Husnan, Suad, 1998, Dasar-dasar Keputusan Investasi, Penerbit BPFE Yogyakarta

Jahja, 1997, Analisis Risk dan Return Terhadap Perusahaan BUMN Sektor Perbankan Yang go Publik di Indonesia, Skripsi, FE TRISAKTI Jakarta.

Marzuki Usman, Singgih Ruphat, dan Syahril Ika. 1997. Pengetahuan Dasar-dasar modal, jurnal keuangan dan moneter dengan Institut Bankir Indonesia, Jakarta.

Mulyatri, 1994, Risiko Portofolio Saham pada Perusahaan Sektor Perbankan Yang go Publik di Indonesia, Skripsi, FE UBH Padang.

Putri, A. D., \& Mayliza, R. (2019). Pengaruh Good Corporate Governance Dan Leverage Terhadap Kinerja Keuangan Pada Perbankan Yang Terdaftar Di BEI. https://doi.org/10.31219/osf.io/b8he7 
Suci Mutia,2009, Analisis Pengaruh Faktor Mikro Dan Makro terhadap Risiko Investasi Saham Di Bursa Efek Indonesia Skripsi Program Studi Manajemen, STIE "KBP” Padang, Tidak dipublikasikan.

Sumantoro. 1990. Pengantar Tentang Pasar Modal di Indonesia, cetakan pertama. Penerbit : Ghalia Indonesia, Jakarta

Tandelilin, Eduardus,2001 Analisis Investasi dan Manajemen Portofolio, Edisi Pertama PT. BPPE, Yogyakarta.

Triwilnawati, 2004, Analisis Pengukuran Risk And Return Investasi Saham Pada Perusahaan Yang Go Public.Skripsi Unand, Padang, Tidak dipublikasikan.

http://www.bi.go.id http://www.bei.co.id http://www.idx.co.id 